\title{
APLIKASI KEUANGAN USAHA PROPERTI PT NAYAKA PRASADA MANDIRI BERBASIS JAVA
}

\author{
Bickri Khidam Assyamsi ${ }^{1}$, Andi Prastomo ${ }^{2}$, Septian Wulandari ${ }^{3}$ \\ Program Studi Teknik Informatika, Fakultas Teknik dan Ilmu Komputer, \\ Universitas Indraprasta PGRI \\ Jalan Raya Tengah No 80, Kelurahan Gedong, Pasar Rebo, Jakarta Timur \\ bickrikhidam@gmail.com ${ }^{1}$, andi_prastomo@ymail.com ${ }^{2}$, septian.pmb09@ rocketmail.com ${ }^{3}$
}

\begin{abstract}
Abstrak
Pada masa modern ini telah banyak perusahaan yang menggunakan aplikasi sebagai alat bantu kerja guna mengolah data-data penting perusahaannya. Namun ada beberapa perusahaan yang masih menggunakan sistem yang seadanya seperti menggunakan aplikasi pengolah katayang keamanan datanya kurang terjamin bahkan ada yang masih menggunakan sistem tulis dalam pendataan perushaannya. Seperti pada kasus ini, peneliti mencoba membuat sistem dalam perusahaan PT Nayaka Prasada Mandiri, dimana perusahan ini masih mengandalkan aplikasi pengolah kata dalam pendataan nya. Data keuangan merupakan data yang penting bagi sebuah perusahaan. Tujuan penelitian ini adalah untuk merancang aplikasi keuangan yang mempermudah bagian pihak perusahaan dalam melakukan olah data customer, cicilan, pemasukkan, pengeluaran, dan arus kas. Serta mempermudah dalam hal membuat laporan keuangan. Adapun metode penelitian yang digunakan oleh peneliti menggunakan metode grounded research sedangkan metode pengembangan sistem menggunakan waterfall.
\end{abstract}

Kata Kunci: Aplikasi Keuangan, Java, Properti.

\begin{abstract}
In modern times, many companies have used applications as a work tool to process important company data. But there are some companies that still use a makeshift system such as using word processing applications whose data security is less guaranteed even some still use writing systems in their company data collection. As in this case, the researcher tried to create a system in the company PT Nayaka Prasada Mandiri, where the company still relies on word processing applications in its data collection. Financial data is important data for a company. The purpose of this research is to design financial applications that make it easier for the company to process customer data, installments, investments, expenses, and cash flow. And make it easier to make financial statements. The research method used by the author uses grounded research methods while system development methods use waterfalls.
\end{abstract}

Keyword: Financial Applications, Java, Property.

\section{PENDAHULUAN}

Sebuah perusahaan pastilah mempunyai data keuangan yang dibutuhkan guna mengkoordinasikan pengeluaran serta pemasukkannya, hal itu digunakan untuk mengetahui seberapa besar keuntungan dan kerugian yang didapat(Romney, Marshall B., 2015). Dalam hal ini PT Nayaka Prasada Mandiri memiliki laporan keuangan yang diolah dalam aplikasi pengolah kata seperti Microsoft Excel dan Word. Pada dasarnya laporan keuangan di bagi menjadi Neraca, laporan laba rugi, dan laporan arus kas (Adam, 2015). Adapun hal yang terjadi pada PT Nayaka Prasada Mandiri, informasi keuangannya masih belum terkomputerisasi dengan baik, juga terdapat kendala dalam pendataan keuangan yang kurang efektif, laporan serta keamanan nya pun yang masih belum tersusun dengan baik dan aman. Dalam hal ini peneliti mencoba membuat suatu sistem dalam bentuk sebuah aplikasi, aplikasi sendiri memiliki artian bagian dari sub kelas perangkat lunak yang ada pada komputer digunakan oleh user untuk melakukan suatu tugas yang user inginkan (Safaat, 2012). Tentu saja dibangunnya aplikasi ini bertujuan untuk mempermudah pihak perusahaan dalam mengolah data keuangan perusahaan serta pencetakan laporan keuangan. Selain itu peneliti juga menggunakan Bahasa pemrograman java dan MySQL sebagai media penyimpanan data.

Java merupakan sebuah nama yang diberikan kepada kumpulan dari teknologi yang digunakan untuk membuat ataupun menjalankan perangkat lunak pada komputer pribadi ataupun pada 
komputer yang terhubung kejaringan (S, 2018). MySQL yang menjadi media penyimpanan bersifat open source yang merupakan salah satu perangkat lunak Database Management System (DBMS) (Widya, 2010). Dalam bentuknya, database terdiri dari sekumpulan tabel yang berisikan data-data yang terkumpul dalam bentuk beberapa field ataupun kolom (Anhar, 2010).

Manfaat penelitian yang dilakukan diharapkan dapat memberikan kemudahan bagi pihak PT Nayaka Prasada Mandiri dalam mengolah data keuangan tersebut dan meningkatkan kualitas kerja bagian keuangan perusahaan. Juga dapat mempermudah pihak perusahaan dalam pembuatan laporan, sebab aplikasi yang dirancang peneliti membuat laporan keuangan secara otomatis. Selain itu juga diharapkan dapat memberikan tambahan referensi kepada peneliti yang mempunyai topik permasalahan yang mirip sehingga sekiranya dapat membantu dalam penyelesaian masalahnya.

\section{PENELITIAN RELEVAN}

Dalam melakukan penelitian Aplikasi Keuangan Usaha Properti PT Nayaka Prasada Mandiri Berbasis Java, peneliti menggunakan 2 sumber bahan referensi yang dibutuhkan untuk pembuataan penelitian ilmiah ini.

Penelitian oleh Untung Rahardja, Qurotul Aini, Marviola Hardini (2018) yang berjudul "Penerapan Software Akuntansi Online Sebagai Penunjang Pencatatan Laporan Keuangan" penelitian ini bertujuan untuk mengembangkan pencatatan peneglolaan keuangan di lingkungan RT 05/02 Kelurahan Paburuan. Adapun peneletian oleh Hendry Andres Maith (2013) berjudul "Analisis Laporan Keuangan Dalam Mengukur Kinerja Keuangan Pada PT. Hanjaya Mandala Sampoerna TBK" penelitian ini bertujuan untuk mengetahui kinerja keuangan pada PT Hanjaya Mandala Sampoerna.

\section{METODE PENELITIAN}

Peneliti menggunakan sebuah metode yang dinamakan metode Grounded Research. Metode ini bertujuan melakukan empiris, menetapkan konsep-konsep yang ada dan kemudian dikembangkan dari fakta yang ada (Cresswell, 2012). Metode pengumpulan data yang dilakukan dalam mendapatkan data-data yang diperlukan dilakukan dalam beberapa macam antara lain:

1. Studi Kepustakaan

Metode pengumpulan data yang dilakukan dengan mempelajari sesuatu yang berhubungan dengan bahasan. Dengan mempelajari buku-buku, sarana perpustakaan dan materi perkuliahan.

2. Observasi

Melakukan pengamatan secara langsung terhadap objek yang menjadi penelitian hal ini berguna untuk mengetahui situasi sebelum dilakukan penelitian di tempat tersebut.

3. Wawancara

Mengajukan pertanyaan secara langsung kepada pihak yang bersangkutan guna mendapatkan informasi-informasi yang diperlukan.

\section{METODE PEN GEMBANGAN SISTEM}

Dalam hal ini metode pengembangan sistem yang digunakan oleh peneliti adalah metode waterfall, metode ini di jelaskan dalam buku (Sommerville, 2011), dalam buku nya dipaparkan "Model air terjun adalah contoh dari proses yang digerakkan dari mulai rencana sampai pada prinsipnya, dimana anda harus merencanakan dan menjadwalkan semua proses kegiatan sebelum mulai mengerjakannya". Langkah-langkah pengembangan sistem: 


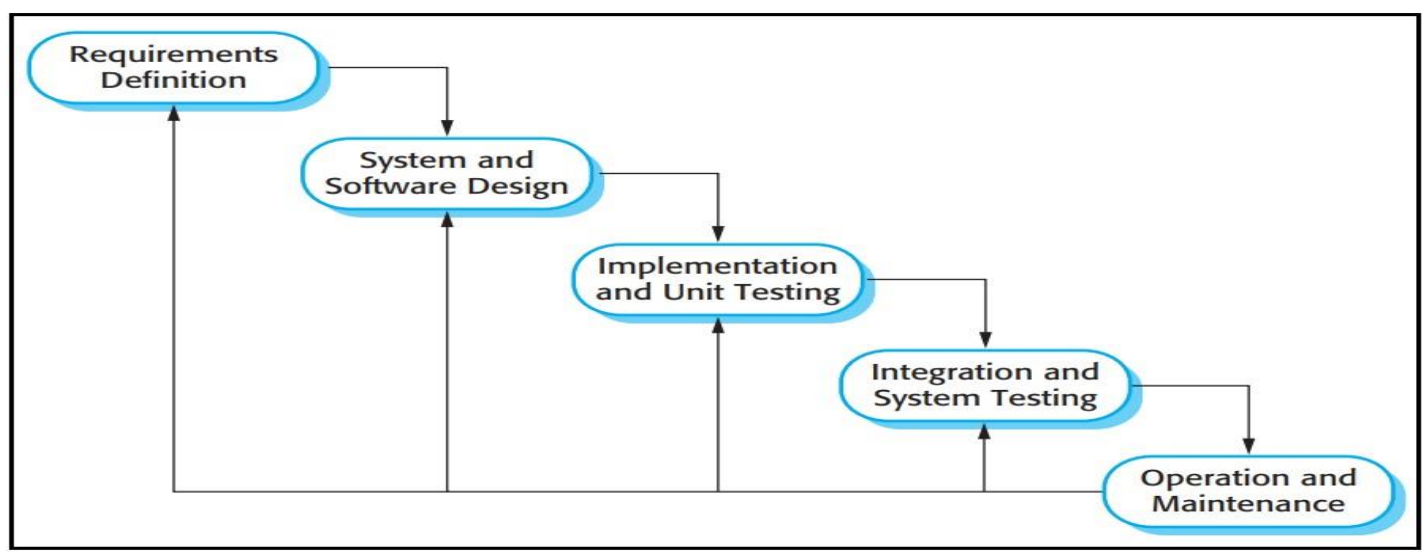

Gambar 1. Langkah-langkah pengembangan sistem

(Sumber: Sommerville, 2011)

\section{Requirements analysis and definition}

Tahapan penetapan fitur, analisa kendala dan tujuan sistem melalui konsultasi dengan pengguna sistem. Semua tahapan tersebut akan ditetapkan secara rinci dan berfungsi sebagai spesifikasi sistem.

\section{System and Software Design}

Tahapan pembentukan arsitektur sistem berdasarkan fakta yang ada pada tahap sebelumnya. Ditahap ini dilakukannya perancangan dasar terhadap sistem yang akan dibuat peneliti yang terdiri dari desain database dan juga desain tampilan.

\section{Implementation and unit testing}

Setelah mendesain database dan tampilan, kemudian dilakukannya pembuatan aplikasi sebagai satu set program ataupun unit program. Kemudian setelah itu setiap unit akan diuji apakah sudah memenuhi spesifikasi yang diinginkan atau belum.

\section{Integration and System testing}

Pada tahap ini aplikasi di uji sebagai satu kesatuan program yang utuh untuk memastikas telah benar-benar memenuhi persyaratan. Kemudian sistem akan dikirim ke pengguna sistem di perusahaan

\section{Operation and Maintenance}

Pada tahap ini juga dilakukan pengujian pada saat sistem dijalankan untuk menemukan dan memperbaiki error yang tidak ditemukan pada tahap pembuatan. Di tahap akhir ini peneliti melakukan pengujian secara keseluruhan untuk memastikan bahwa sudah tidak sistem atau fitur yang error pada aplikasi nya sehingga aplikasi sudah siap pakai untuk pengguna nya.

\section{HASIL DAN PEMBAHASAN}

\section{Diagram Alir Data (DAD)}

Diagram Alir Data merupakan suatu jaringan kerja yang menggambarkan hubungan antara sistemsistem baik itu secara manual, otomatis ataupun gabungan dari keduanya yang saling berhubungan. digambarkan menggunakan simbol yang digambarkan sesuai aturannya (Sutabri, 2014). 


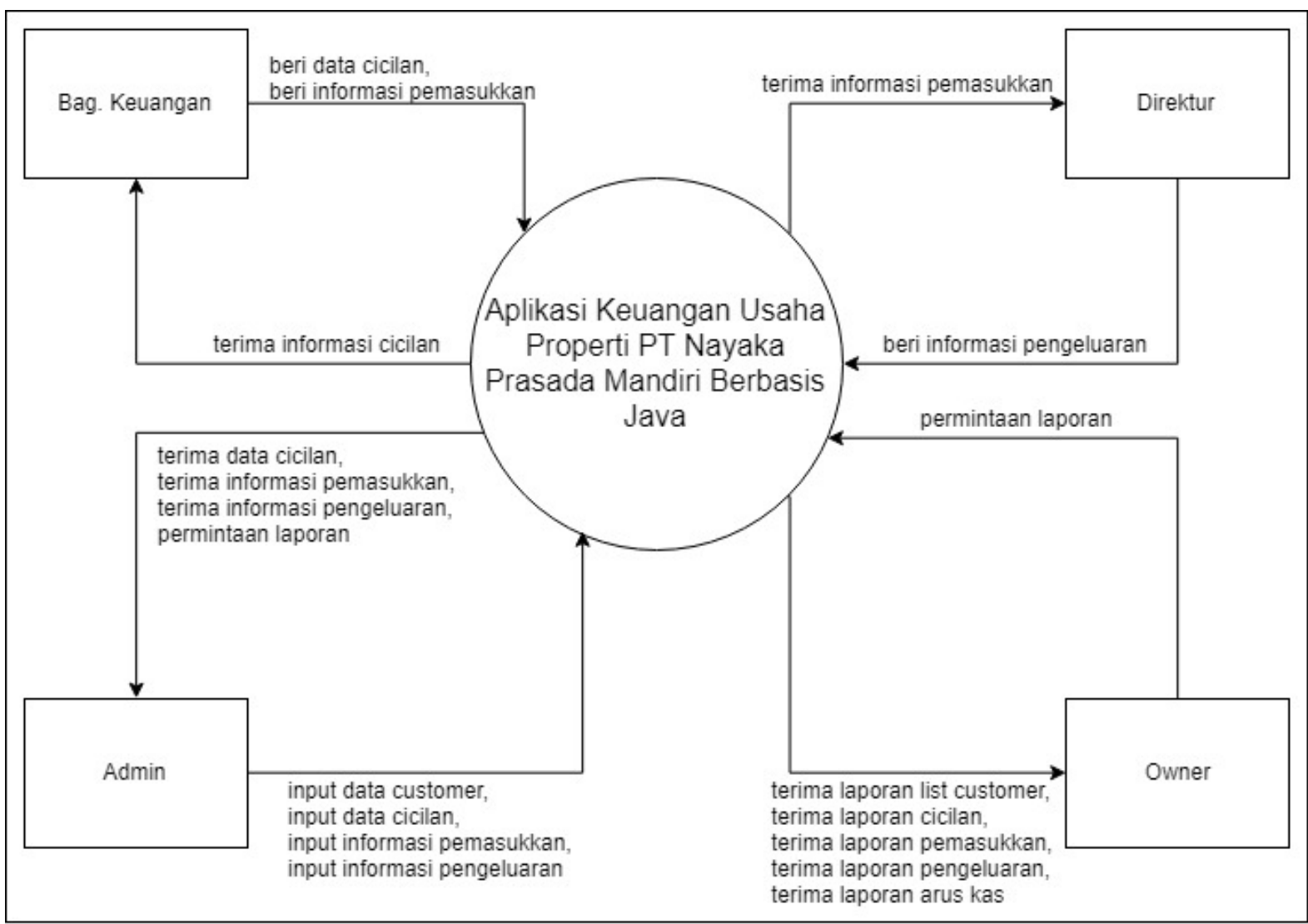

Gambar 2. Diagram Alur Data

\section{Entity Realtionship Diagram (ERD)}

ERD biasanya digunakan untuk menjelaskan hubungan suatu hubungan antar entitas yang ada pada suatu sistem. Biasanya digambarkan dalam bentuk notasi ataupun simbol untuk menggambarkan hubungan antar data-data nya (Haryanto, 2011).

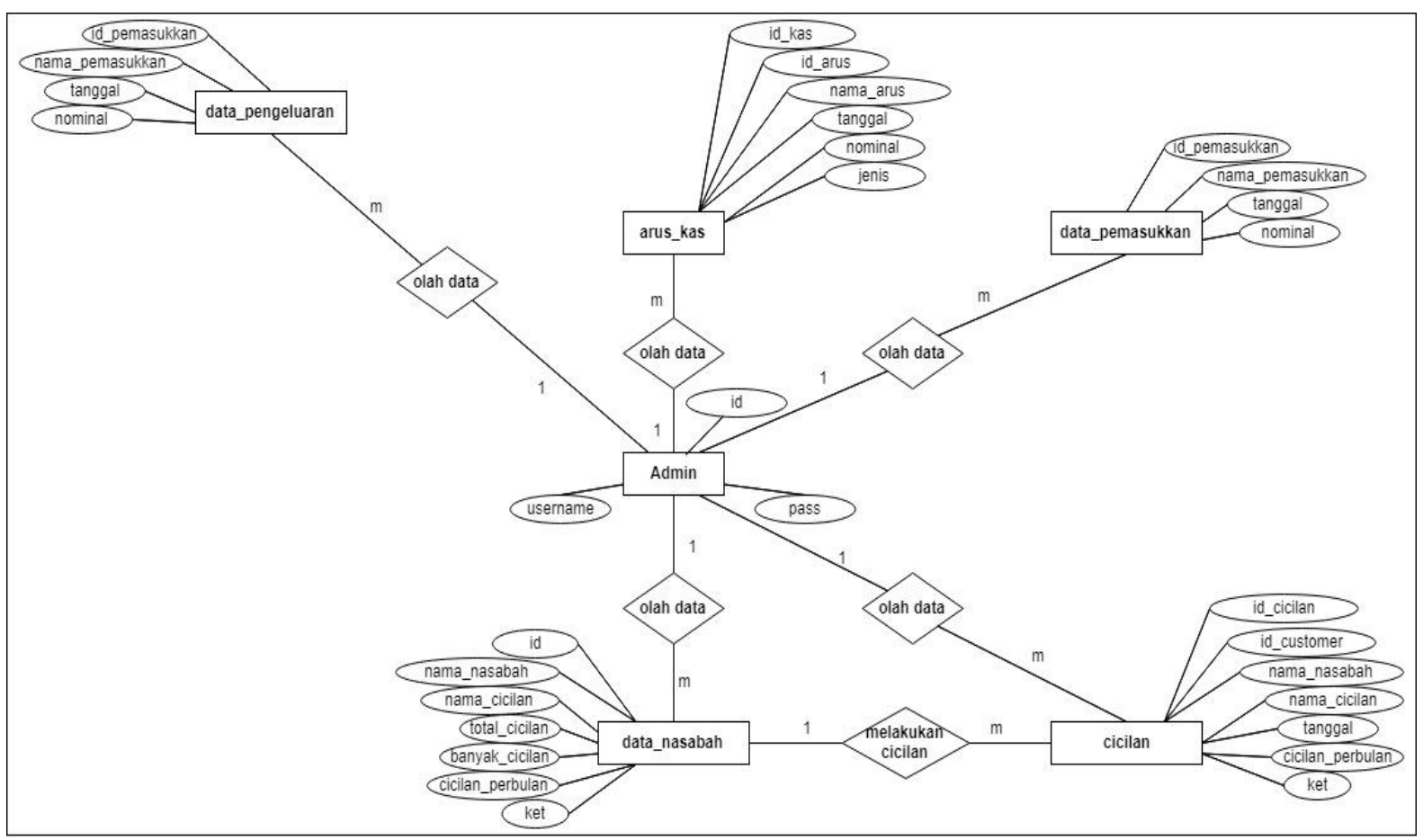

Gambar 3. Entitiy Relationship Diagram (ERD) 


\section{Tampilan Aplikasi}

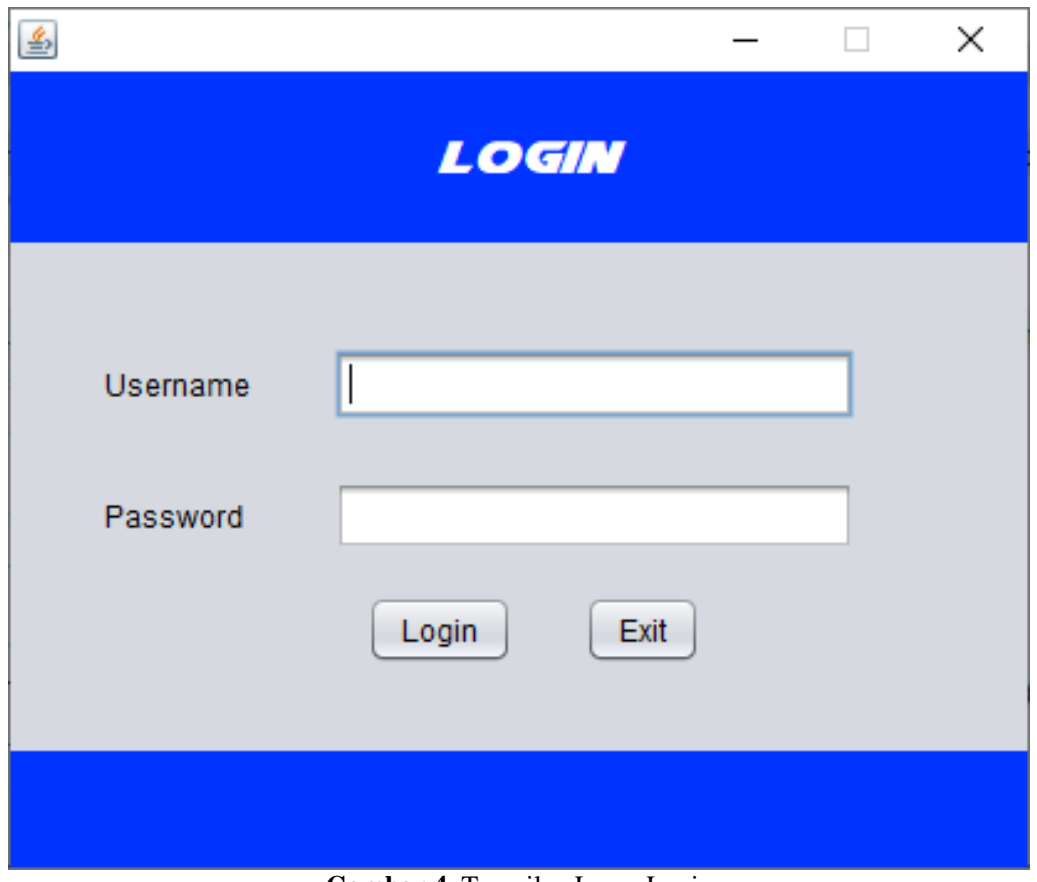

Gambar 4. Tampilan Layar Login

Tampilan login diatas menampilkan tampilan layar awal pada saat pertama kali user membuka apliaksi, yang berisi tombol login dan exit. Tombol ogin berfungsi apabila user ingin menuju menu utama

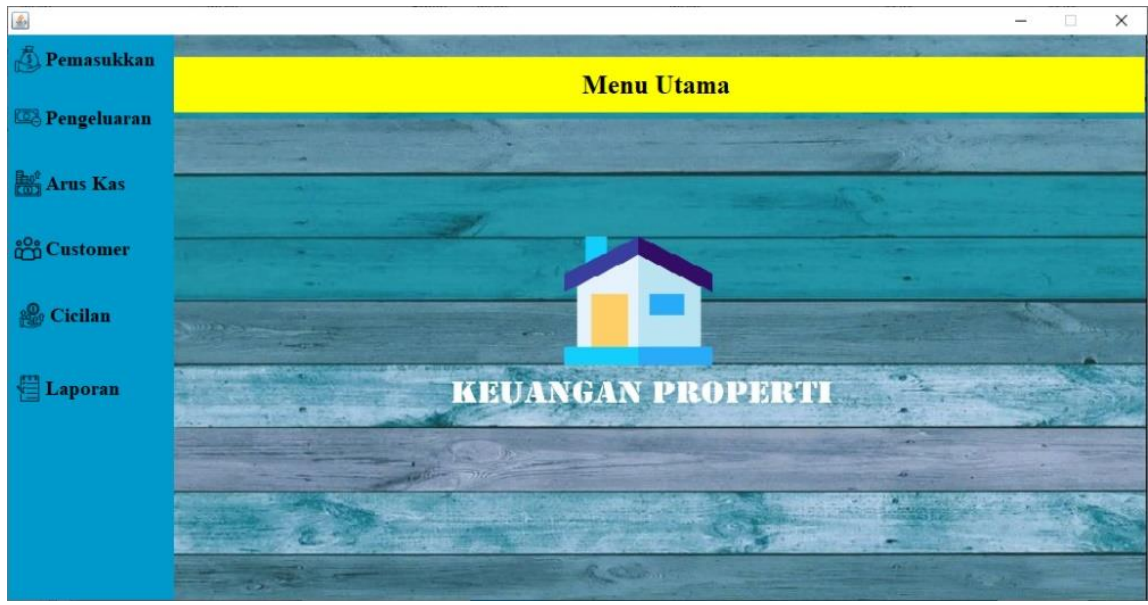

Gambar 5. Tampilan Layar Menu Utama

Tampilan menu utama diatas menampilkan tampilan layar awal pada saat pertama kali login, yang berisi menu-menu seperti pemasukkan, pengeluaran, arus kas, customer, cicilan dan laporan. 


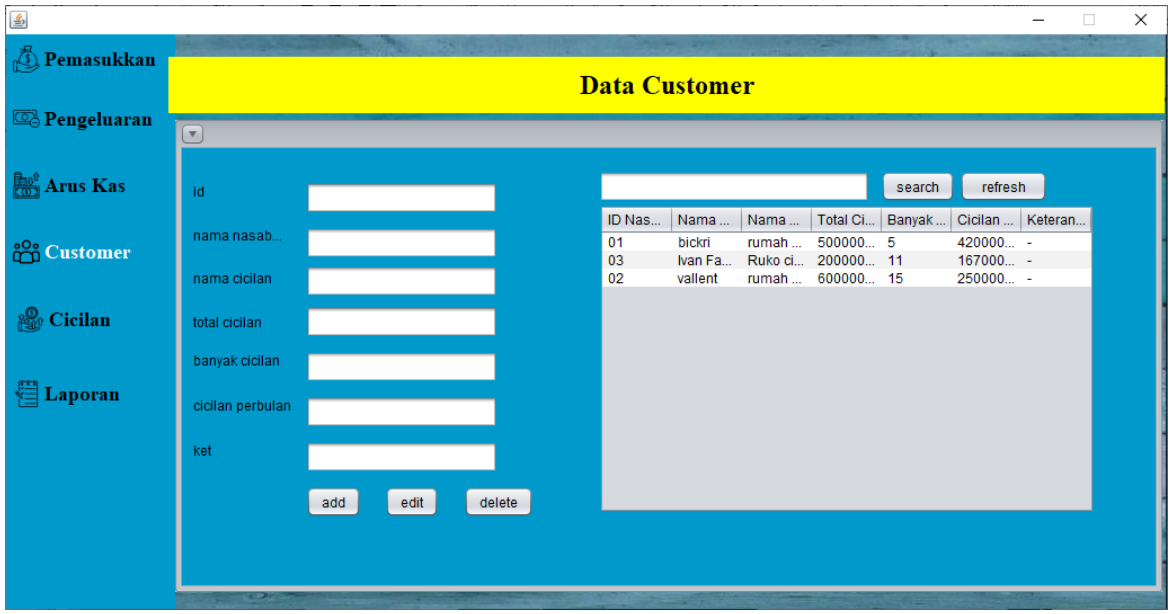

Gambar 6. Tampilan Layar Data Customer

Tampilan layar data customer memiliki beberapa tombol yang dapat digunakan untuk menambah, mengedit dan menghapus file data customer. Fungsi panel kiri digunakan untuk isi data customer sedangkan panel bagian kanan digunakan untuk menampilkan data customer.

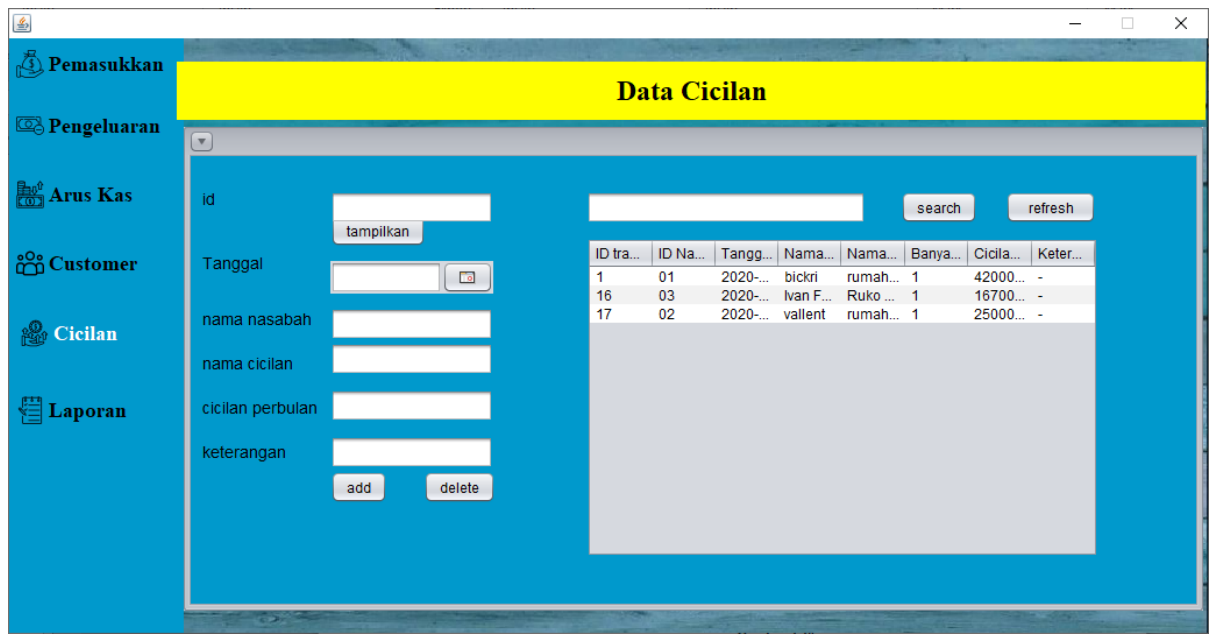

Gambar 7. Tampilan Layar Data Cicilan

Tampilan layar data cicilan memiliki beberapa tombol yang dapat digunakan untuk menambah dan menghapus data cicilan. Fungsi panel kiri digunakan untuk isi data cicilan sedangkan panel bagian kanan digunakan untuk menampilkan data cicilan.

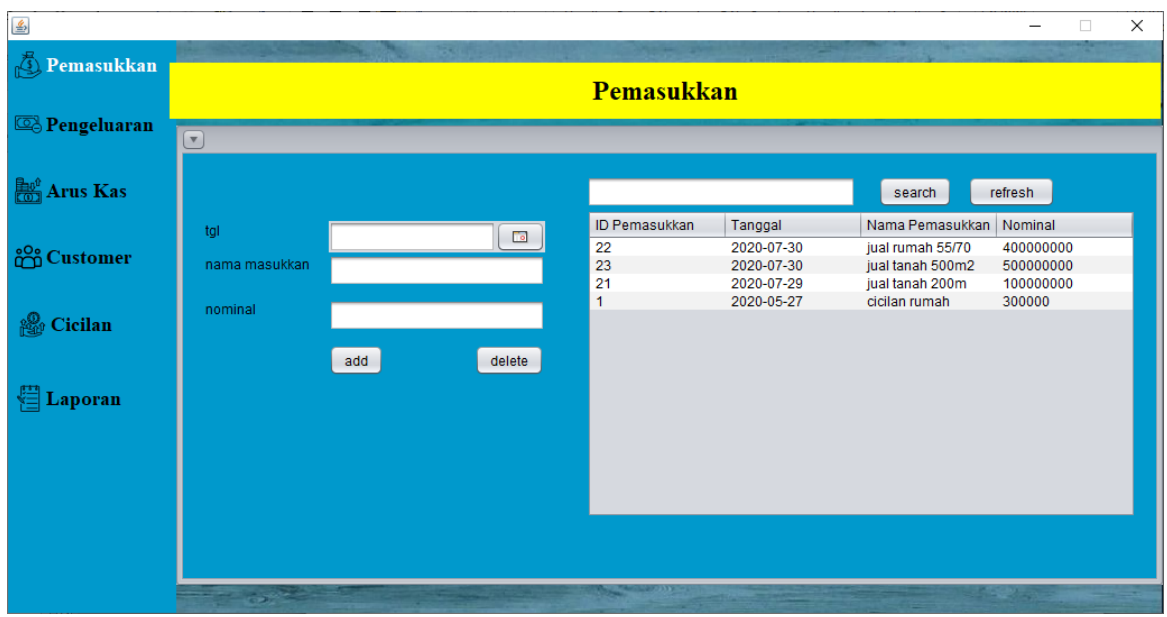

Gambar 8. Tampilan Layar Data Pemasukkan 
Tampilan layar data pemasukkan memiliki beberapa tombol yang dapat digunakan untuk menambah dan menghapus data pemasukkan. Fungsi panel kiri digunakan untuk isi data pemasukkan sedangkan panel bagian kanan digunakan untuk menampilkan data pemasukkan.

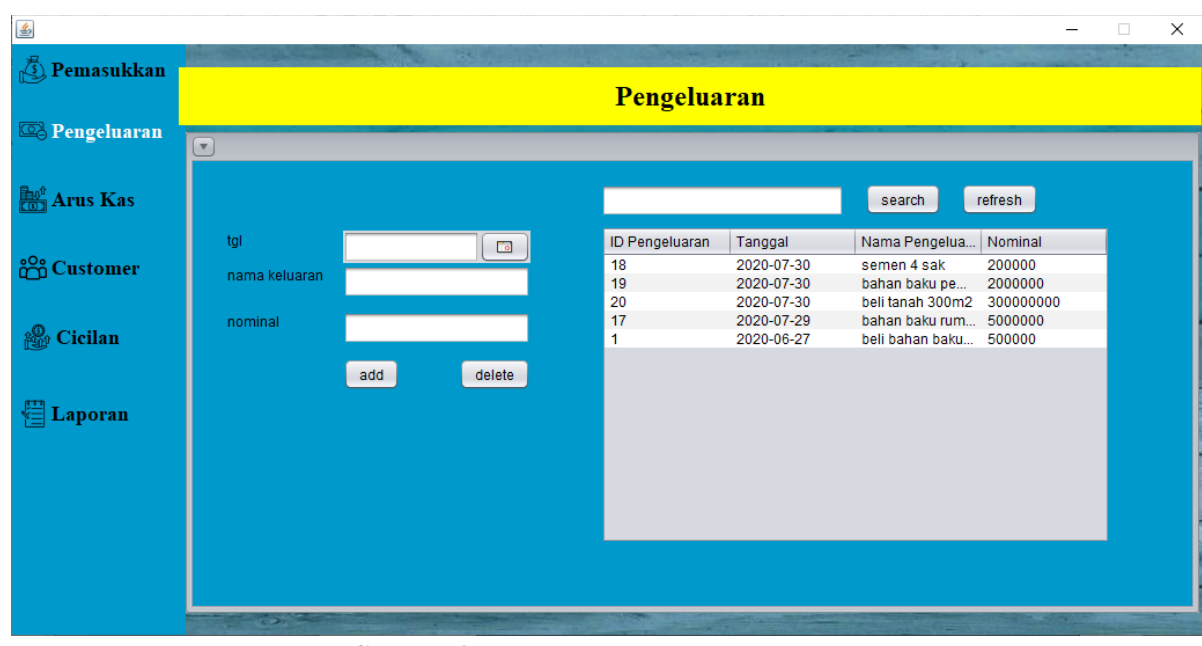

Gambar 9. Tampilan Layar Data Pengeluaran

Tampilan layar data pengeluaran memiliki beberapa tombol yang dapat digunakan untuk menambah dan menghapus data pengeluaran. Fungsi panel kiri digunakan untuk isi data pengeluaran sedangkan panel bagian kanan digunakan untuk menampilkan data pengeluaran.

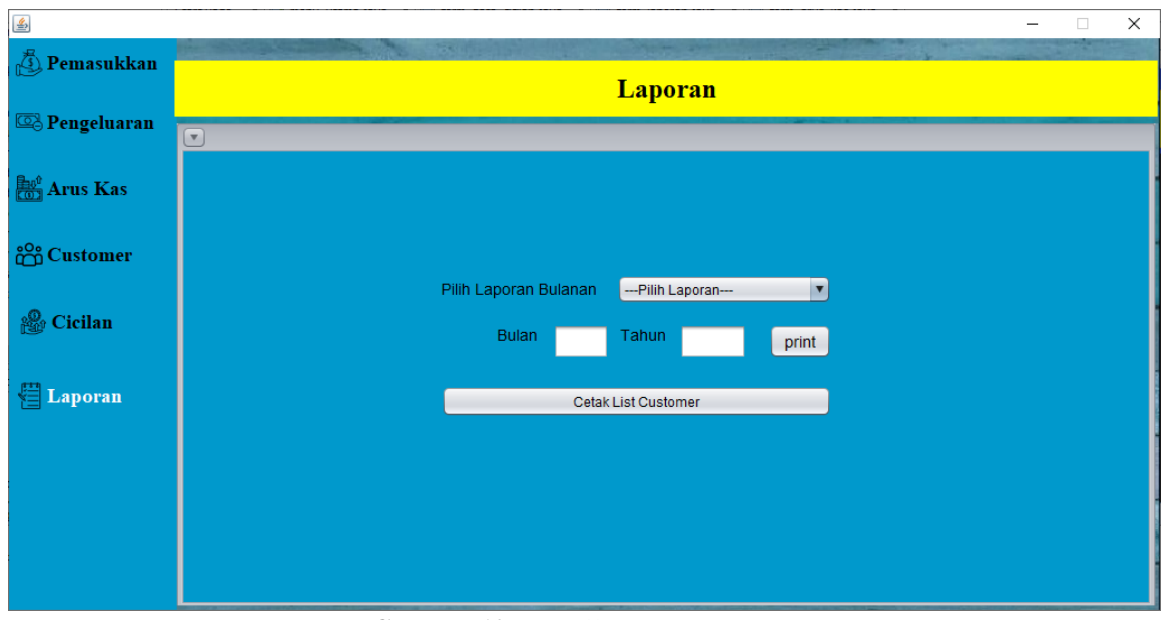

Gambar 10. Tampilan Layar Laporan

Tampilan layar laporan memiliki beberapa tombol yang dapat digunakan untuk mencetak laporan. Kolom di isi bulan dan tahun untuk menentukan cetak laporan bulanan 


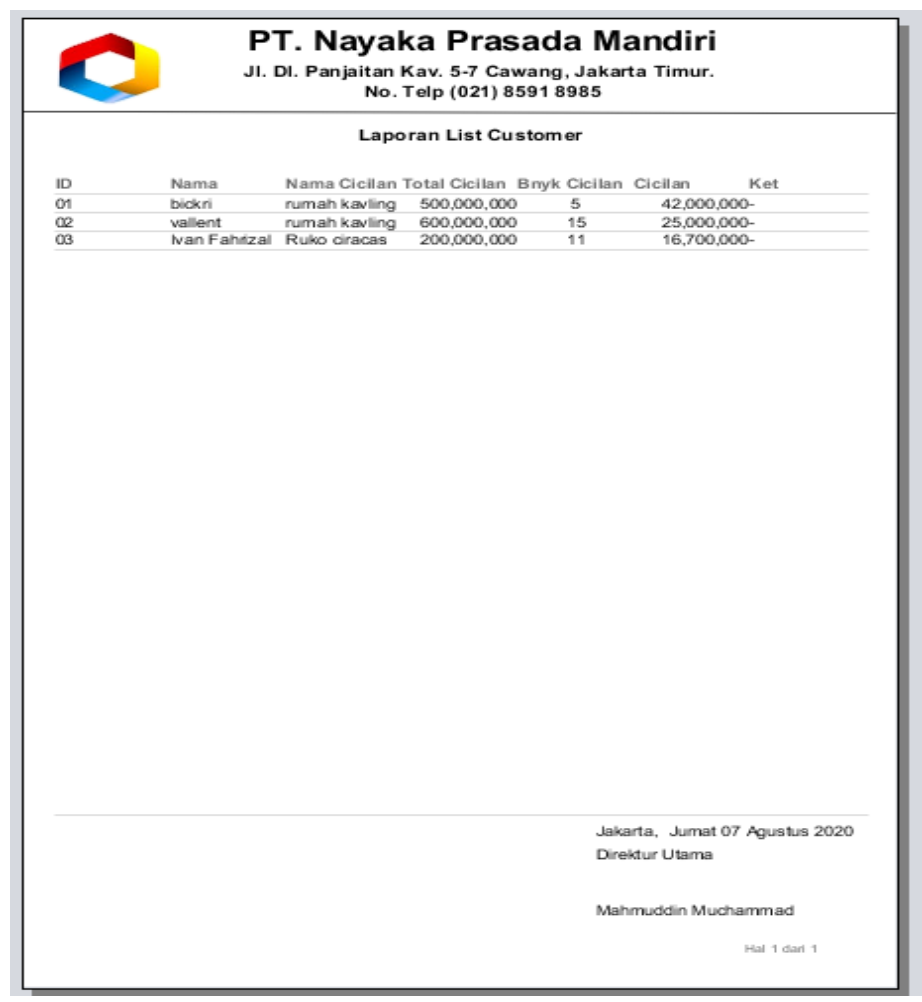

Gambar 11. Tampilan Laporan List Customer

Tampilan laporan list customer menampilkan isi dari data-data yang ada pada aplikasi yang kemudian menghasilkan suatu tampilan laporan. Hal ini juga berlaku terhadap tampilan laporan cicilan, pemasukkan, pengeluaran dan arus kas.

\section{SIMPULAN}

Secara umum peneliti menyimpulkan bahwa sarana prasarana kegiatan pemasaran suatu produk dalam kasus peneliti adalah perumahan, ruko dan tanah. Dalam produktivitas dan efektivitas proses pemasaran di PT Nayaka Prasada Mandiri dimana perlunya manajemen keuangan yang baik. Secara lebih khusus peneliti berhasil membuat aplikasi keuangan pada PT Nayaka Prasada Mandiri, memberikan kemudahan kepada pihak pemilik PT Nayaka Prasada Mandiri dalam melakukan pencatatan jual, beli, dan dalam melakukan manajemen keuangan perusahaan. Dan mempermudah dalam pembuatan laporan keuangan yang sudah dirancang secara otomatis.

\section{DAFTAR PUSTAKA}

Adam, H. (2015). Accounting Principle : Melalui pendekatan sistem informasi. Fak. Ilmu Komputer dan Sistem Informasi Univ. Kebangsaan.

Anhar. (2010). PHP \& MySQL Secara Otodidak. PT.Transmedia. Cresswell. (2012). Educational Research (Edisi 4). Pearson Education.

Haryanto, B. (2011). Esensi-esensi Bahasa Pemrograman Java. Andi.

Romney, Marshall B., dan P. J. S. (2015). Accounting Information Systems (13th ed). Pearson Educational Limited.

S, R. A. (2018). Logika Algoritma dan Pemrograman Dasar. Modula.

Safaat, N. (2012). Pemrograman Aplikasi Mobile Smartphone dan Tablet PC Berbasis Android. Informatika.

Sommerville, I. (2011). Software engineering. Pearson Education.

Sutabri, T. (2014). Pengantar Teknologi Informasi (Edisi Pert). Andi.

Widya. (2010). Panduan Menguasai PHP \& MySQL Secara Otodidak. PT.Transmedia. 